\title{
Investigation of Availability of Raw Perlite in Refractory Building Material Production
}

\author{
Ergün Yeșilyurt ${ }^{1}$, Osman Ş̧imşek $^{2}$, Ahmet Bilgil $^{3}$ \\ ${ }^{1}$ Kayseri Vocational College,CivilAviation School,ErciyesUniversity, Kayseri-Turkey,yesile@erciyes.edu.tr \\ ${ }^{2}$ Faculty of Technology, Department of Civil Engineering, GaziUniversity, Ankara-Turkey, simsek@ gazi.edu.tr \\ ${ }^{3}$ Department of Civil Engineering, NiğdeÖmerHalisdemir University,Niğde-Turkey, abilgil@ ohu.edu.tr
}

\begin{abstract}
Article Info
Article history:

Received Oct $17^{\text {th }}, 2017$

Revised Oct $26^{\text {th }}, 2018$

Accepted Feb 16 ${ }^{\text {th }}, 2018$
\end{abstract}

\begin{abstract}
Perlite having rich reserves in Turkey is basic industrial raw material in line with sustainable development objectives. In recent years due to the thermal insulation properties expanded perlite has attracted the attention of researchers. It is started to use in some construction areas. Binder material is used to shape in the manufacturing of refractory bricks. Desired material was sintered at high temperature. In this study, perlite between 75-600 $\mu \mathrm{m}$ particle size was subjected to heat treatment at different temperatures and investigated to use in refractory construction materials production. Perlite grains clinging to each other engage a smooth shape. Gypsum is used as an activator in different proportions to achieve this objective. The samples were subjected to heat treatment at $1050-1200{ }^{\circ} \mathrm{C}$ for 30 minutes. In the $5 \%$ gypsum mixture highest compressive strength at $1150{ }^{\circ} \mathrm{C}$ was calculated as $47 \mathrm{MPa}$. Unit volume weight is considered as $1.95 \mathrm{~g} / \mathrm{cm}^{3}$, water absorption by weight is determined as $0.30 \%$. Superficial abrasion loss was determined to be $20 \mathrm{~mm}$. Degree of porosity is calculated as $15 \%$. Compactness was found to be $85 \%$. Furthermore in the results of experiment of freezing of the obtained products was not found any damage or any strength loss.
\end{abstract}

\section{Corresponding Author:}

ErgünYeşilyurt

Kayseri Vocational College,CivilAviation School, ErciyesUniversity, 38039 Kampüs, Melikgazi-KAYSERİ, TURKEY

Email: yesile@erciyes.edu.tr

\section{Introduction}

The main objective of sustainable development is defined as "deliberate consumption of resources without harming to natural resources". Depends on developing technology, many raw materials were evaluated in industry. Perlite is one of the industrial raw materials. Perlite is an amorphous volcanic glass that has relatively high water content, typically formed by the hydration of obsidian. It occurs naturally and has the unusual property of greatly expanding when heated sufficiently. Therefore perlite has been brought to the millimeter size. Grains were dehydrated in $850-1150^{\circ} \mathrm{C}$ in the flame shock. In this way the volume of particles increased by 35 times. This heat insulating building materials are manufactured taking advantage of expansion feature.

In studies realized in recent years to produce bricks, expanded perlite is added to the raw brick in specific proportions. In this way, physical and mechanical properties of the bricks can be examined [1], [2]. In the carrier lightweight concrete production researches, a certain amount expanded perlite is usually replaced with normal aggregate. In this way, it has been examined mechanical and physical properties of the concrete [3], 
[4]. In another study, expanded perlite and ponza was used as aggregate together in the lightweight concrete production. While the rate of pearlite aggregate increased the density of concrete decreased [5]. In recent years waste has been constructively applied to resources in recycling research, and related achievements are seen in engineering applications. Several researchers have been investigating the incorporation of different types of residues in the manufacture of traditional ceramic materials in recent years [6], [7]. The availability of industrial waste water treatment plants collected from sludge brick manufacturing were studied. The produced brick shrinkage, pressure and water absorption test were conducted. Test result showed that the two major factors that determine the ratio and firing temperature of the slurry brick quality [8], [9]. Marble dust accumulating in the sedimentation pool, lime, gypsum and expanded perlite was utilized when producing bricks. This produced material is suitable for the production of lightweight wall blocks with observed mechanical properties [10]. Perlite dust is a mineral additive for concrete and cement. This situation has positive effect on compressive strength [10], [11], [12].

According to studies, the binder material is used to shape in the manufacture of refractory bricks from 0.5 to 5 $\mathrm{mm}$ size. Requested material cooked at high temperatures. Brick raw material, in the presence of highly $\mathrm{SiO}_{2}$ $(93 \%-98 \%)$ at high temperature can be expanded a ratio of about $3.5 \%$. When exposed to $870{ }^{\circ} \mathrm{C}$, quartz is known to turn into tridymite. This allotropic transformation has been continued with crystobalit [13].

The $\mathrm{Al}_{2} \mathrm{O}_{3}-\mathrm{SiO}_{2}$ component group that have more than $45 \% \mathrm{Al}_{2} \mathrm{O}_{3}$ content has been called as high alumina bricks. Their refractory properties have been good. They were resistant to abrasion. They have been resistant against high pressure in cold and hot environment. They have been low resistant against acid based slag. But they have been resistant against base based slag and against thermal shock [14], [15], [16].

Generally, alumina refractory materials have alumina content of between $45 \%$ and $99 \%$. Bricks, manufactured with these materials have relatively high substitution rates in terms of the technical and mechanical properties [17]. Usually in accompaniment material, damage occurred. These have been realized through cracking or breaking. These have been realized during weight loss through grain throwing [14], [18], [19], [20].

The effects of the chemical composition on the mechanical properties in the refractory materials containing alumina in different ratios were studied. Refractory materials may contain alumina of 50 percent or 60 percent or 70 percent. Between mechanical properties and chemical compositions a linear relationship was not observed [21], [22].

Isolated monolithic refractory materials production was tested in compliance with ASTM standards. Diatomite, expanded perlite and pumice have been used. After the samples were dried, they were baked at 925 ${ }^{\circ} \mathrm{C}$. Density and strength and shrinkage ratio of the samples have been determined. After drying, sample density was found $0.94 \mathrm{~g} / \mathrm{cm}^{3}$. Baking shrinkage ratio at $925{ }^{\circ} \mathrm{C}$ was determined as $-1.7 \%$. Compression strength was found as $1.9 \mathrm{MPa}$ [23].

Marble powder, clay and industrial waste pyrophyllite were subjected to different cooking temperatures between 900 and $1200{ }^{\circ} \mathrm{C}$ for producing ceramic materials. Manufactured products were considered in terms of water absorption and mineralogical properties [24].

Reduction in thermal conductivity of the accompanying materials with increased porosity was possible. There is also the effect of the distribution and size of pores. Overall thermal conductivity has been depended on the chemical composition, porosity and temperature. Furthermore crystalline compositions, mineralogical composition of the blend, particle size, cooking temperature and glassy phase type of the present crystalline have been important [24].

There are several studies on perlite as a bulding material indicating that it can be used in various areas of civil engineering and most of them are commercialized. Same of them are LanzónandGarcía-Ruiz [25], Sengul et al. [26], Okuyucu [27], KramarandBindiganavile [28], Mamun et al. [29], Sriwattanapong et al. [30], GandageAbhijeet et al. [31], Kramar, andBindiganavile [32], Keskin et al. [33], Erdoğan and Sağlık [34], Bozkurt [35], Bakhtiyari et al. [36], Darweesh [37], Ramezanianpour et al. [38], Oktay et al. [39], Dawood [40], Binici and Kalayc1 [41], Is1kdag [42], Maaloufa et al. [43], Jedidi et al. [44], Zhang et al. [45], Chung et al. [46], Abidi et al. [47], Shoukry et al. [48], Abidi et al. [49], Taherishargh et al. [50], Taherishargh et al. [51] andKrivenko et al. [52].

Perlite reserves are almost not considered in the present construction industry.Raw perlite aggregate, after being shaped in certain sizes, is subjected to heat treatment in different degrees. This process implemented with the aid of binder material and building material is intended to be produced. 


\section{Experimental Investigation}

Perlite milled at the 75-600 $\mu \mathrm{m}$ size used in this study was obtained from Cappadocia. The total perlite reserve of the basin is approximately 350 million tons [53]. Gypsum was used as binder for shaping of the test sample and was mixed with water as calcium based material. After 8 minutes a reaction has been started according TSEN 13279-1 "Structure and Plaster" standard [54]. Perlite was used in proportion to the amount of plaster used in the mixture. In this study city water was used.

The petrographic and chemical analysis of the raw perlite has been performed in Erciyes University Technology Development Center (TEKMER), and the results are given in following Table1.

Table 1. Chemical analysis of perlite

\begin{tabular}{lcccccccccc}
\hline $\begin{array}{l}\text { Chemical } \\
\text { united }\end{array}$ & $\mathrm{SiO}_{2}$ & $\mathrm{CaO}$ & $\mathrm{Al}_{2} \mathrm{O}_{3}$ & $\mathrm{Fe}_{2} \mathrm{O}_{3}$ & $\mathbf{M g O}$ & $\mathrm{K}_{2} \mathrm{O}$ & $\mathrm{Na}_{2} \mathrm{O}$ & $\mathrm{Cl}$ & $\mathbf{S O}_{3}$ & L.O.I. \\
\hline$(\%)$ & 71.01 & 1.48 & 12.87 & 2.25 & 0.21 & 4.46 & 3.42 & 0.20 & - & 3.57 \\
\hline
\end{tabular}

\subsection{Sample production}

In this study, in order to produce samples, grinded and riddled by $600 \mu \mathrm{m}$ griddle raw perlite and gypsum are used. In $100 \%$ raw perlite samples, because of being not able to make horizontal-vertical transfers, plaster is used as binder. Samples are produced in 40x40x160 mm standart dimensions and produced based on weight rather than volume. In mixture, gypsum as a 5, 10, 15, 20\% of weight of perlite is used with water until mixture becomes consistence of plastic. Experiment groups which are given in Table 2 are formed based on gypsum ratios and sintering temperatures for sample production and mixtures are prepared by a bench-type mixer.

Table 2. Sample number based on mixture ratios and sintering temperatures

\begin{tabular}{ccccccc}
\hline & \multicolumn{6}{c}{ Sample numbers and sintering temperatures $\left({ }^{\circ} \mathbf{C}\right)$} \\
\cline { 2 - 6 } Sample & $\mathbf{1 0 0 0}$ & $\mathbf{1 0 5 0}$ & $\mathbf{1 1 0 0}$ & $\mathbf{1 5 0 0}$ & $\mathbf{1 2 0 0}$ & Total \\
\cline { 2 - 5 } group* & $\mathrm{S}_{\mathrm{T} 1}$ & $\mathrm{~S}_{\mathrm{T} 2}$ & $\mathrm{~S}_{\mathrm{T} 3}$ & $\mathrm{~S}_{\mathrm{T} 4}$ & $\mathrm{~S}_{\mathrm{T} 5}$ & \\
\hline $\mathrm{S}_{5}$ & 12 & 12 & 12 & 12 & 12 & 60 \\
$\mathrm{~S}_{10}$ & 12 & 12 & 12 & 12 & 12 & 60 \\
$\mathrm{~S}_{15}$ & 12 & 12 & 12 & 12 & 12 & 60 \\
$\mathrm{~S}_{20}$ & 12 & 12 & 12 & 12 & 12 & 60 \\
Total & 48 & 48 & 48 & 48 & 48 & 240 \\
\hline
\end{tabular}

*Subscript $(5,10,15$ and 20) shows plaster ratio as weight in mixture.

SubscriptT1, shows sample groups formed by sintering temperatures.

Samples are taken out from mold after 60 minutes. Samples which are formed based on sintering temperature are dried 10 hours at $100+-5^{\circ} \mathrm{C}$ in a seramicowen which could reach $1300{ }^{\circ} \mathrm{C}$ maximum temperature. Then for different groups temperature is increased up to $1000,1050,1100$ and $1200{ }^{\circ} \mathrm{C}$ by $5{ }^{\circ} \mathrm{C}$ increase per minute and sintered 30 minutes at these temperature levels.

In this study, it is observed that samples gained mechanical properties after 30 minutes sintering and the values of these properties increased proportional to increase in sintering time. In thermal analysis, 30 minutes sintering times at which samples gain mechanical and physical properties taken as reference. However, in $1000{ }^{\circ} \mathrm{C}$ sintering temperature case is not considered because mechanical properties are not observed. Materials used and samples produced in this study has been shown in Fig. 1.

One axis compressive strength experiments, unit volume weights, water absorbtion percentages, percentage porosities, corrosion resistance values and filling rates analyses which meets the requirements of TS EN standarts applied on samples with different sintering temperatures and different plaster ratios by weight as 
binder. Results are calculated by taking arithmetic mean of each group samples. However, in order to observe corrosion resistance values new samples with same parameter values but different dimension are produced. Acording to results of experiments optimum 30 minutes sintering temperatures and gypsum mixture ratios are determined.
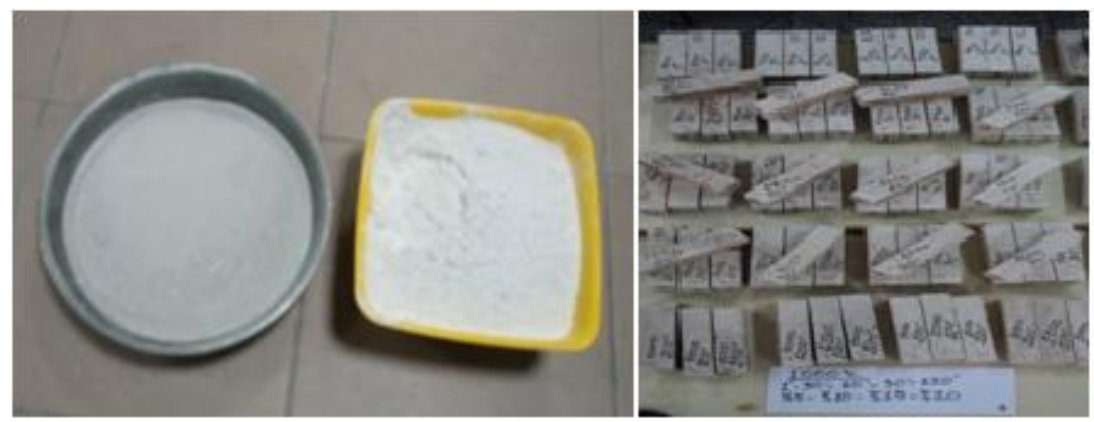

Figure 1. Thermal processed samples with raw perlit-based gypsum binded

\section{Results and Discussion}

\subsection{Examination of the physical and mechanical properties}

The weight per unit volume of sample is given graphically in Fig. 2. The compressive strength of the samples at $850,900,950$ and $1000^{\circ} \mathrm{C}$ is not defined. These values are detected at $1050,1100,1150$ and $1200{ }^{\circ} \mathrm{C}$ as 30 minutes cooking time and are shown in Fig. 3 graphically. In addition, the compressive strength and unit volume weight relationship was shown in Fig. 4-8 graphically.

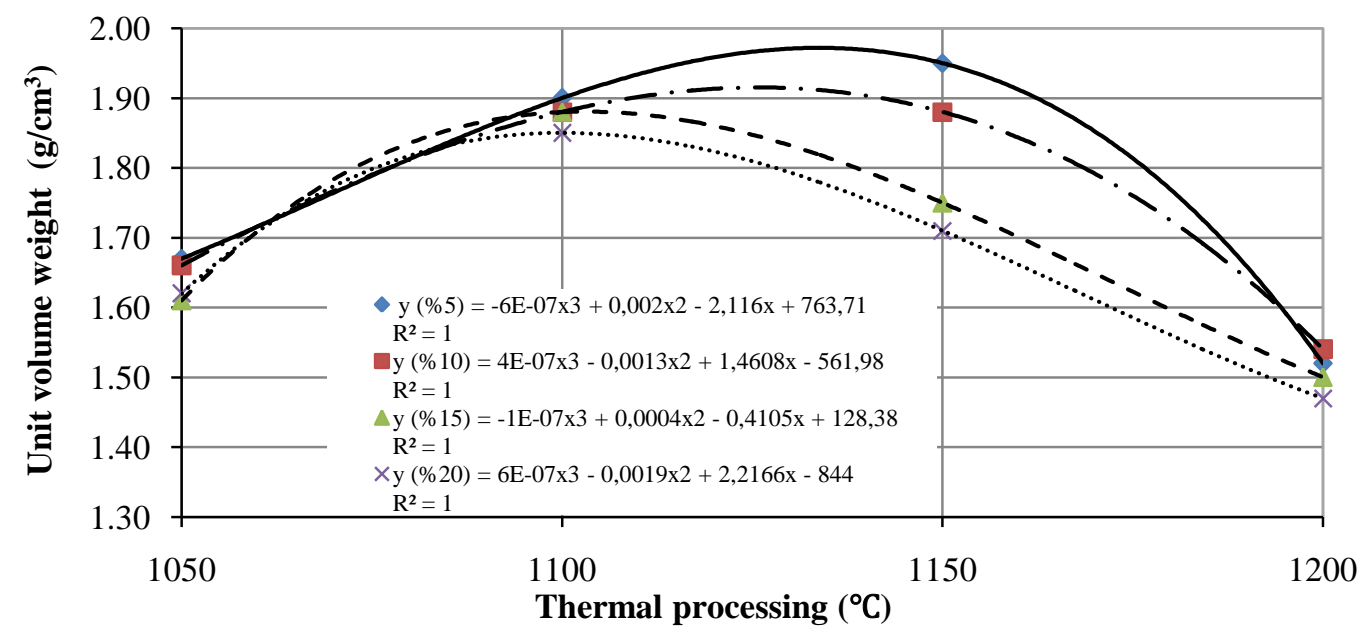

Figure 2. Different thermal processing-unit volume weight relationships of the samples

When Fig. 2 is observed, $\mathrm{R}^{2}=1$ is the regression coefficient of third degree parabolic relationship. Highest unit volume weight has been belonged to the samples produced by $5 \%$ gypsum. These samples were subjected to heat treatment at $1150{ }^{\circ} \mathrm{C}$ and the obtained value has been $1.95 \mathrm{~g} / \mathrm{cm}^{3}$. While some examples were heat treated at the same temperature, minimum unit volume weight has been obtained. These samples were produced with $20 \%$ gypsum. The obtained value has been $1.71 \mathrm{~g} / \mathrm{cm}^{3}$. There are many differences between unit volume weights of the samples heat-treated at this temperature. Unit volume weights of the heat treated samples at $1100{ }^{\circ} \mathrm{C}$ have been very close together. Highest unit volume weight has been belonged to the samples produced by $5 \%$ gypsum and the obtained value has been $1.90 \mathrm{~g} / \mathrm{cm}^{3}$. Minimum unit volume weight has been belonged to the samples produced by $20 \%$ gypsum and the obtained value has been $1.85 \mathrm{~g} / \mathrm{cm}^{3}$. Unit volume weights of the heat treated samples at $1200^{\circ} \mathrm{C}$ have been very close together. Highest unit volume weight has been belonged to the samples produced by $10 \%$ gypsum and the obtained value has been $1.54 \mathrm{~g} / \mathrm{cm}^{3}$. Minimum unit volume weight has been belonged to the samples produced by $20 \%$ gypsum and the obtained 
value has been $1.47 \mathrm{~g} / \mathrm{cm}^{3}$. Generally, increment in the gypsum binder ratio leads to a reduction in unit volume weight.

The changes that occur during cooking with increasing degree of heat treatment were observed at a greater rate. These changes were observed as vitrification, shape and volume changes, fragility and capillary cracking. Although pore structure was increased, water absorption is reduced due to the vitrification. In this case the weight per unit volume will decrease.

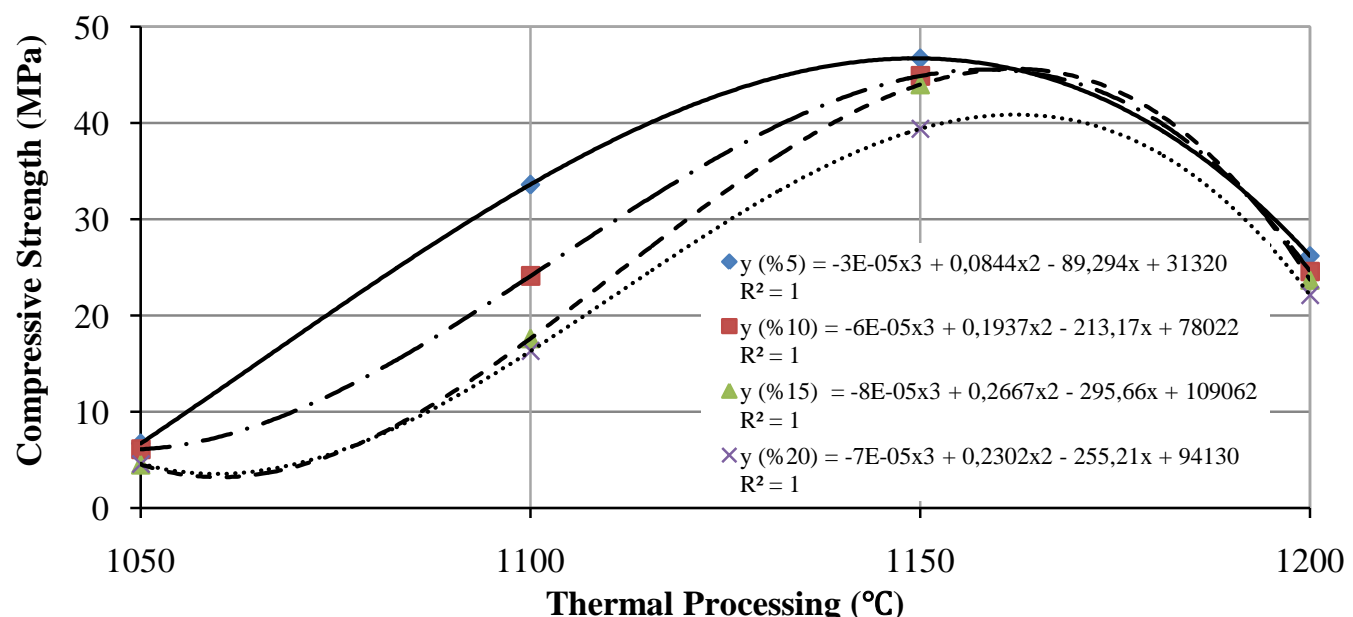

Figure 3. Different thermal processing-compressive strength relationships of the samples

When Fig. 3 is observed, $R^{2}=1$ is the regression coefficient of third degree strong parabolic relationship in all gypsum rates. Highest unit volume weight has been belonged to the samples produced by $5 \%$ gypsum. These samples were subjected to heat treatment at $1150{ }^{\circ} \mathrm{C}$ and the obtained value has been $46.7 \mathrm{MPa}$. While some examples were heat treated at the same temperature, minimum unit volume weight has been obtained. These samples were produced with $20 \%$ gypsum. The obtained value has been $39.4 \mathrm{MPa}$. There are many differences between compressive strengths of the samples heat-treated at this temperature. Compressive strengths of the heat treated samples at $1050{ }^{\circ} \mathrm{C}$ have been very close together. Highest compressive strength has been belonged to the samples produced by 5\% gypsum and the obtained value has been $6.7 \mathrm{MPa}$. Minimum compressive strength has been belonged to the samples produced by $15 \%$ gypsum and the obtained value has been 4.5 MPa. Compressive strength of the heat treated samples at $1200^{\circ} \mathrm{C}$ has been very close together. Highest compressive strength has been belonged to the samples produced by $5 \%$ gypsum and the obtained value has been 26.2 MPa. Minimum compressive strength has been belonged to the samples produced by $20 \%$ gypsum and the obtained value has been $22.1 \mathrm{MPa}$. Generally, increment in the gypsum binder ratio leads to a reduction in compressive strength.

Samples produced by heat treatment in $5 \%$ gypsum mix at all temperatures have high strength. Lime rate increase implies a reduction in the compressive strength. The changes that occur during cooking with increasing degree of heat treatment were observed at a greater rate. These changes were observed as vitrification, shape and volume changes, fragility. The heat treatment temperature could not been taken low enough value to form the metallic bondstrength to the atomic material. If this was not in case then the material would not have beenmonolithic. 


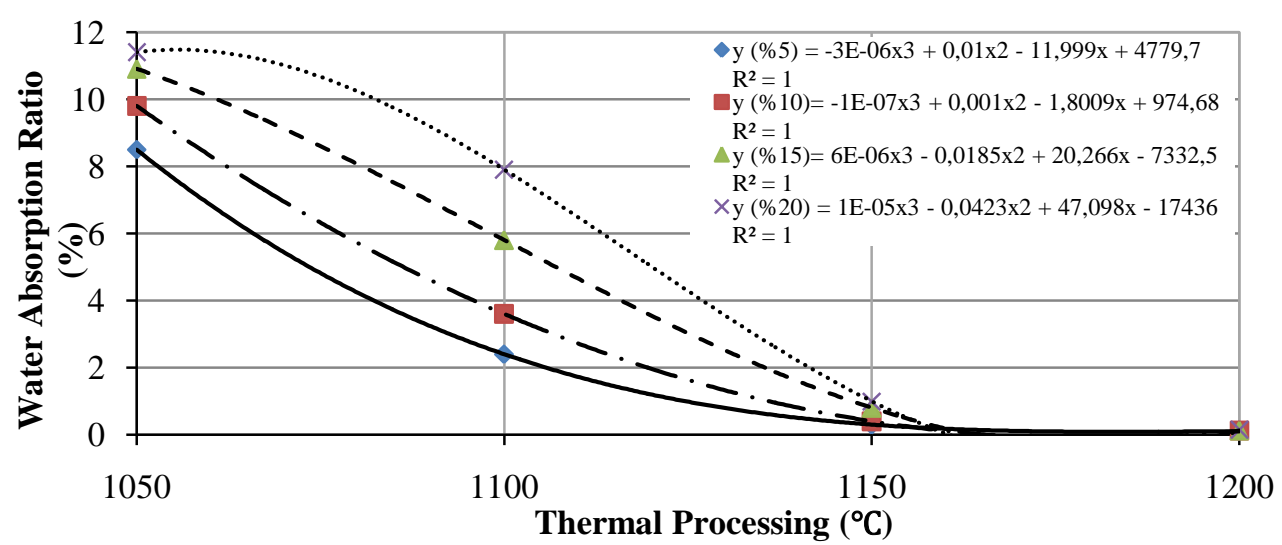

Figure 4. Different thermal processing-water absorption ratio relationships of the samples

When Fig. 4 is observed, $R^{2}=1$ is the regression coefficient of third degree strong parabolic relationship in all gypsum rates. Heat treatment temperature increase implies a reduction in the water saturation ratio. This ratio has been even close to zero for $1200^{\circ} \mathrm{C}$. Highest water saturation has been belonged to the samples produced by $20 \%$ gypsum. These samples were subjected to heat treatment at $1050{ }^{\circ} \mathrm{C}$ and the obtained value has been $11.4 \%$. While some examples were heat treated at the same temperature, minimum water saturation has been obtained. These samples were produced with $5 \%$ gypsum. The obtained value has been $8.5 \%$. By the same temperature heat treatment with increased gypsum ratio, the water saturation has been increased. Maximum water saturation has been belonged to the samples produced by $20 \%$ gypsum. The obtained value has been $0.15 \%$. Minimum water saturation has been belonged to the samples produced by $5 \%$ gypsum. The obtained value has been $0.10 \%$. Generally, increased rate of the gypsum binder leads to an increase for water saturation.

Heat treatment temperature increase implies a reduction in the water saturation ratio. Obviously, this reduction was realized due to the vitrification. The heat treatment temperature could not been taken low enough value to form the metallic bond strength to the atomic material. If this was not in case then the material would not have been monolithic.

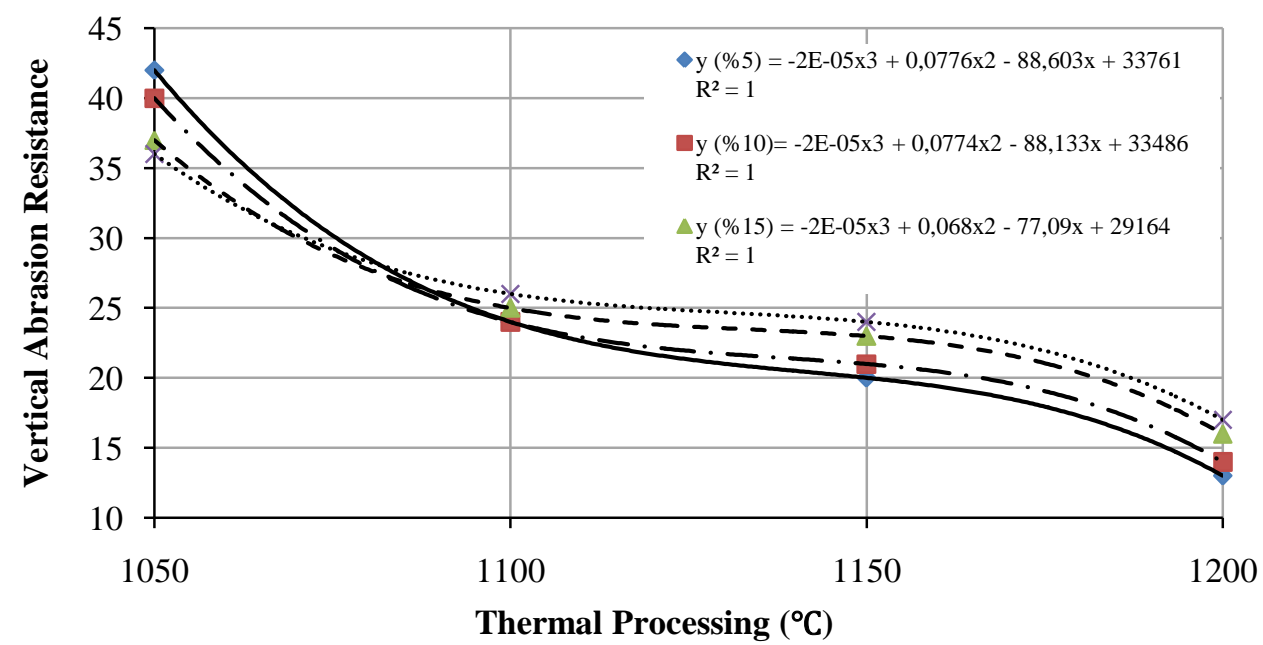

Figure 5. Different thermal processing-vertical abrasion resistance relationships of the samples

When Fig. 5 is observed, $\mathrm{R}^{2}=1$ is the regression coefficient of third degree strong parabolic relationship in all gypsum rates. Highest vertical abrasion resistance has been belonged to the samples produced by $5 \%$ gypsum. These samples were subjected to heat treatment at $1050{ }^{\circ} \mathrm{C}$ and the obtained value has been $42 \mathrm{~mm}$. Then, vertical abrasion resistance decreases with increasing temperature, whereby an inverse linear relationship. At the end $1200{ }^{\circ} \mathrm{C}$ temperature the obtained value is $13 \mathrm{~mm}$.

Vertical abrasion resistances of the heat treated samples at $1100{ }^{\circ} \mathrm{C}$ have been very close together.Vertical abrasion resistances of the heat treated samples at $1200{ }^{\circ} \mathrm{C}$ have been very close together. Highest vertical 
abrasion resistance has been belonged to the samples produced by $20 \%$ gypsum and the obtained value has been $17 \mathrm{~mm}$. Minimum vertical abrasion resistance has been belonged to the samples produced by $5 \%$ gypsum and the obtained value has been $13 \mathrm{~mm}$.

The changes that occur during cooking with increasing degree of heat treatment were observed at a greater rate. These changes were obviously observed as vitrification. In this case vertical abrasion resistance will increase. Therefore abrasion loss will decrease.

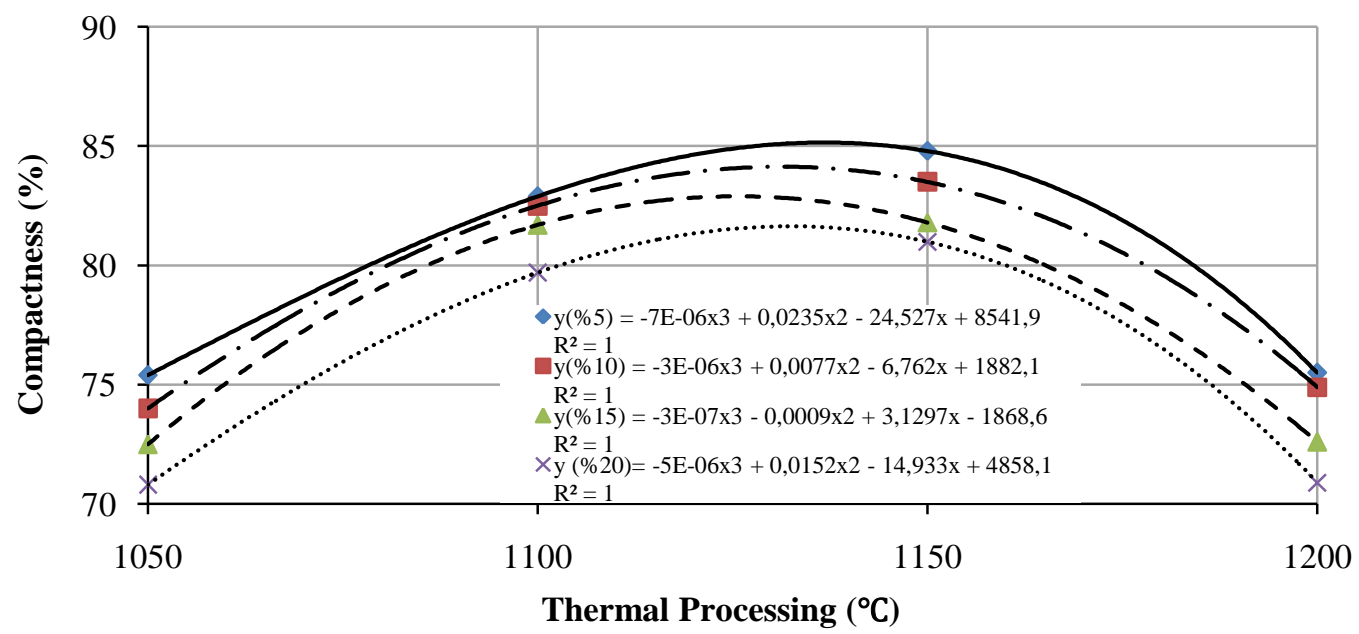

Figure 6. Different thermal processing - compactness relationships of the samples

Compactness, determined in this study was obtained by calculating as in Fig. 6. When Fig. 6 is observed, $\mathrm{R}^{2}=1$ is the regression coefficient of third degree strong parabolic relationship in all gypsum rates. Highest compactness has been belonged to the samples produced by $5 \%$ gypsum. These samples were subjected to heat treatment at $1150{ }^{\circ} \mathrm{C}$ and the obtained value has been $85 \% .1050$ and $1200{ }^{\circ} \mathrm{C}$ have been the minimum compactness temperature for samples treated with heat. These samples have been produced with $20 \%$ gypsum. The obtained value has been $71 \%$. According to this analysis, increased rate of the gypsum leads to a decrease for compactness ratio.

The changes that occur during cooking with increasing degree of heat treatment were observed at a greater rate. These changes were obviously observed as vitrification. Because of this change; a strong resemblance has been seen between unit volume weight, compressive strength and compactness (\%). This situation is compatible with the basic principles of materials science.

In this study for the most appropriate sample, $1150{ }^{\circ} \mathrm{C}$ has been thought as the heat treatment temperature. This sample has been belonged to the samples produced by $50 \%$ gypsum binder. In this example unit volume weight, compressive strength, water saturation, vertical abrasion resistance and compactness values are considered as $1.95 \mathrm{~g} / \mathrm{cm}^{3}, 46.7 \mathrm{MPa}, 0.3 \%, 20 \mathrm{~mm}$ and $84.8 \%$. The results of freezing and thawing have been observed. It has not been detected any loss or damage for the sample.

\subsection{Examination of the micro-structural properties}

In this study, micro-structural properties of the raw and processed perlite have been investigated.SEM images were analyzed for the samples activated with the gypsum activator. These samples were subjected to a high temperature. Some other samples were not subjected to high temperature. SEM images were analyzed for these raw samples. Micro structural properties of SEM images were evaluated using Scanning Electron Microscope. The samples have been prepared with gypsum and were then baked. Heat treatment effect can be seen clearly with the SEM images. SEM images at different scales for raw perlite were shown in Fig. 7.a and b. The raw perlite was taken as a reference sample. 


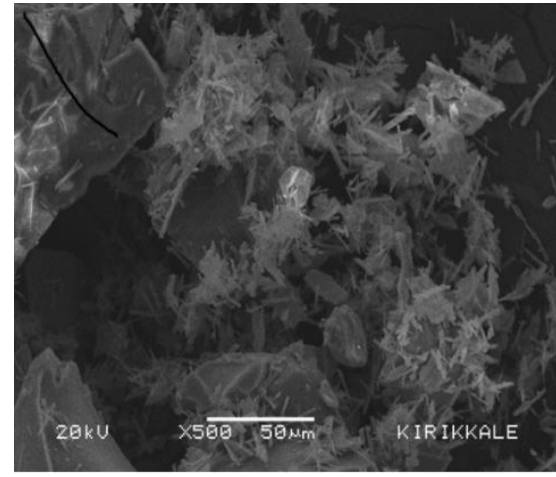

a - 500x magnification

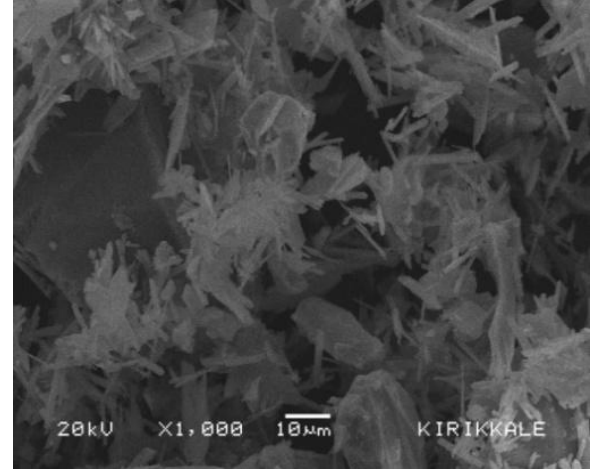

b - 1000x magnification

Figure 7. a. and b. SEM images for reference sample that have not been treated with heat.

Reference samples did not heat-treated. Structural changes were not seen in general mortar structure. The hollow structure of the mortars is observed. A very rare observed structure has been also adhesion bond.

Samples were heat-treated at different temperature. SEM images have been related to the samples heat-treated at $1150{ }^{\circ} \mathrm{C}$. Results are shown in Fig. 8aand b. In this heat treated magnified SEM image there was high temperature effect. The mortar structure changes are changes available for heat-treated samples arising from changes in the temperature. The density of the mortar is increased with increase in temperature. If mortar density increases, the structure of space is reduced.

Flat surface and material integrity were achieved with the effect of high temperature. In the 500x magnified SEM image fused parts are seen together by melted parts. In 2000x magnified SEM image fused parts are seen clearly in a perlite structure.

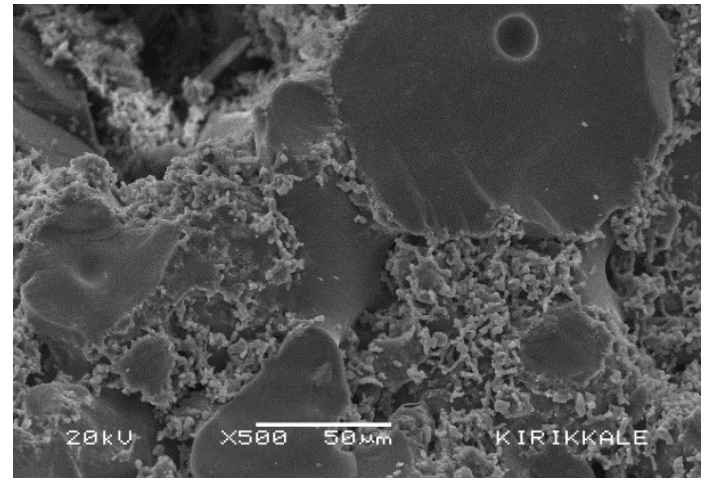

a - 500x magnification

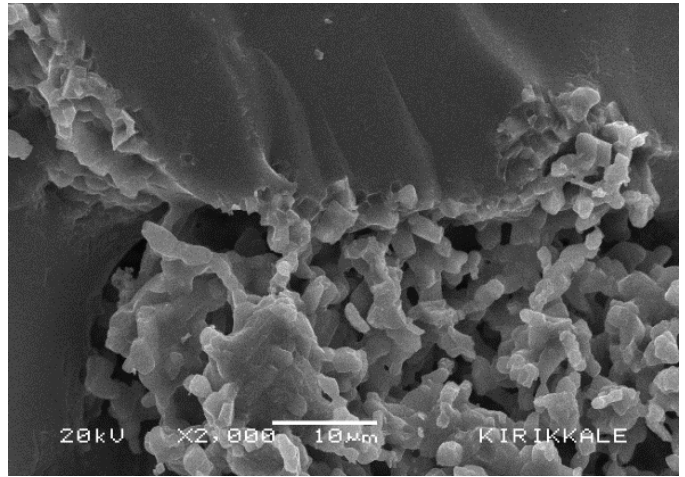

b - 2000x magnification

Figure 8. a. and b. SEM image for sample that has been treated with heat at $1150{ }^{\circ} \mathrm{C}$

\section{Conclusions}

This study has been done in order to utilize perlite which is assumed as inert material in industry. Perlite is binded by gypsum after grinding and exposed 30 minutes sintering, then the results are given below have been obtained.

1- Groups which are formed by using gypsum as weight of 5,10,15 and 20\% are sintered at 1000, 1050, 1100,1150 and $1200{ }^{\circ} \mathrm{C}$. Axial compression stress of the samples which are sintered at $1000{ }^{\circ} \mathrm{C}$ could not be obtained. Maximum axial compressive stress values are obtained from the groups which sintered at $1150{ }^{\circ} \mathrm{C}$. According to gypsum ratios, maximum compressive stress value is obtained from $5 \%$ gypsum samples at a level as $46.7 \mathrm{MPa}$.

2- In samples are sintered at $1150{ }^{\circ} \mathrm{C}$, at which maximal compressive strength is obtained, it is observed that unit volume weigths are decreased by increasing gypsum ratios. Minimum unit volume weights are observed at the samples which are sintered at $1200{ }^{\circ} \mathrm{C}$. At this temperature level, raw perlite 
showed a tendency to expand independent from gypsum ratio and similar resultsare obtained for all gypsum-mixed samples.

3- At $1150{ }^{\circ} \mathrm{C}$ sintering temperature, because it is close to melting point of perlite all mitures showed a tendency to be vitrificated and water absorbtion ability is quite reduced. Moreover, water absorbtion ability decreases proportional to decrease in gypsum rate. At $1200{ }^{\circ} \mathrm{C}$, water absorbtion levels observed as zero for all gypsum-mixed samples.

4- Corossion resistance of samples are increased by increasing sintering temperature. Corossion is minimum at $1200{ }^{\circ} \mathrm{C}$ but even at $1150{ }^{\circ} \mathrm{C}$ corrosion performance values are better than $\mathrm{C} 30$ concrete.

5- Maximum compactness ratio is observed at $1150{ }^{\circ} \mathrm{C}$. Compactness increase by increasing gypsum ratio. For $5 \%$ gypsum samples, $85 \%$ compactness rate has been reached.

6- According to the physical and mechanical values, optimum sintering temperature acknowledged as $1150{ }^{\circ} \mathrm{C}$ in for sample production.

In conclusion, mechanical properties take the first place in the parameters which are expected from concretes and rocks. Properties of the product obtained from raw perlite, which is assumed as inert material, by sintering at $1150{ }^{\circ} \mathrm{Cwith} 5 \%$ gypsum are better than most of the concretes and rocks. Other physical parameters of the product also meets the requirements in the standarts. By the results of this study, it is observed that perlite based products could be used as both vertical and horizontal innovative contruction materials. However, for this material, the effects of sintering times on change in physical and mechanical properties are need to be investigated.

\section{Compliance with Ethical Standards:}

Conflict of Interest: The authors declare that they have no conflict of interest.

\section{References}

[1] İ.B. Topçu, B. Işıkdağ, "Manufacture of high heat conductivity resistant clay bricks containing perlite," Building and Environment, 42, pp. 3540-3546, 2007.

[2] A. Ceylan, V. Uz, E. Taşc1, "The effects of raw perlite and extended perlite adding in terracotta bodies," IV. International Eskişehir Terra Cotta Symposium, Turkey, 2010, pp. 199-215.

[3] İ. Turkmen, A. Kantarc1, "Effects of expanded perlite aggregate and different curing conditions on the physical and mechanical properties of self-compacting concrete," Building and Environment, 42, pp. 2377-2383, 2007.

[4] İ.B.Topçu, B. Işıkdağ, "Effect of expanded perlite aggregate on the properties of light weight concrete," Journal of Materials Processing Technology, 204, pp. 34-38, 2008.

[5] R. Demirboğa, İ. Örüng, R. Gül, "Effects of expanded perlite aggregate and mineral admixtures on the compressive strength of low density concretes," Cement and Concrete Research, 31, pp. 1627-1632, 2001.

[6] M. Dondi, G. Ercolani, G. Guarini, M. Raimondo, "Orimulsion fly ash in clay bricks-part 1: composition and thermal behaviour of ash," Journal of the European Ceramic Society, 22, pp. 17291735, 2002.

[7] M. Dondi, M. Marsigli, B. Fabbri, "Recycling of industrial and urban wastes in brick production- a review," Tile \& brick international, 13, pp. 218-315, 1997.

[8] D.F. Lin, C.H. Weng, "Use of sewage sludge ash as brick material," Journal of Environmental Engineering,127, pp. 922-927, 2001.

[9] C.H. Weng, D.F. Lin, P.C. Chiang, "Utilization of sludge as brick materials," Advances in Environmental Research, 7, pp. 679-685, 2003.

[10] I. Demir, M.S. Başpınar, "Use of marble dust on lightweight building block production," IX. Marble Symposium in Turkey, 2003, pp. 213-220.

[11] L.H. Yu, H. Ou, L.L. Lee, "Investigation on puzzolanic effect of perlite powder in concrete," Cement and Concrete Research, 33, pp. 73-76, 2003. 
[12] T.K. Erdem, Ç. Meral, M. Tokyay, T.Y. Erdoğan, "Use of perlite as a puzzolanic addition in producing blended cements," Cement and Concrete Composites, 29, pp. 13-21, 2007.

[13] A. Şahin, "Refractory Materials, Refractories and industrial furnaces lecture notes," http://malzemebilimi.net/ September, 2017.

[14] D.P.H. Hasselman, "Unified theory of thermal shock fracture initiation and crack propagation in brittle ceramics," Journal of the American Ceramic Society, 52, pp. 600-604, 1969.

[15] T. Husovic, R. Jancic, M. Cvetkovic, M. Mitrakovic, Z. Popovic, "Thermal shock behavior of alumina based refractories: fracture resistance parameters and water quench test," Materials Letters, 38, pp. 372378, 1999.

[16] N.S. Köksal, B.S. Ünlü, Ç. Meriç, "Investigation of thermal shock behaviourin alumina based refractory bricks," Pamukkale University Engineering College, Journal of Engineering Sciences, 9, pp. 147-151, 2003.

[17] "Turkish Commission of Industrial Raw Materials, Raw materials working group report on ceramic, refractory, glass," Under secretary of Turkish State Planning Organization, Ankara-Turkey, Vol. 2, 1995.

[18] J. Nakayama, M. Ishizuka, "Experimental evidence for thermal shock damage resistance," Ceramic Bulletin, 45, pp. 666-669, 1966.

[19] A.G. Lanin, A.L. Tkachev, "Numerical method of thermal shock resistance estimation by quenching of samples in water," Journal of Materials Science, 35, pp. 2353-2359, 2000.

[20] A.V. Shevchenko, K. Ruban, V. Dudnik, "Highly-workable alumina-base ceramics," Refractorie sand Industrial Ceramics, 41, pp. 1-10, 2000.

[21] N.S. Köksal, "Investigation of mechanical properties of alumina refractory material," Technological Research: Electronic Journal of Machine Technology, 3, pp. 23-28, 2005.

[22] L. Wang, J.L. Shi, H.R. Chen, Z.L. Hua, T.S. Yen, "Effect of size of the starting powders on the thermal shock resistance of alumina ceramics," Journal of Materials Science Letters, 20, pp. 341-342, 2001.

[23] G. Ulusoy, "Pumice using isolated monolithic materials manufacture," Bulletin of the Mineral Research and Exploration, (MTA Journal), 129, pp. 89-96, 2004.

[24] M.A. Montero, M.M. Jordán, M.B. Almendro-Candel, T. Sanfeliu, M.S. Hernández-Crespo, "The use of calcium carbonate residue from the stone inndustry in manufacturing of ceramic tile bodies," Applied Clay Science, 43, pp. 186-189, 2009.

[25] M. Lanzón, P.A. García-Ruiz, "Lightweightcementmortars: advantagesandinconveniences of expanded perlite anditsinfluence on freshandhardenedstatedurability,"ConstructionBuildingMaterial, 22, pp. 1798-1806, 2008.

[26] Ö. Sengul, S. Azizi, F. Karaosmanoglu, M.A. Tasdemir, "Effect of expanded perlite on themechanicalpropertiesandthermalconductivity of lightweightconcrete,"EnergyBuilding, 43, pp. 671676, 2011.

[27] D. Okuyucu, B. Uzal, L. Turanli, T. Tankut, "Somecharacteristics of fibre-reinforced semilightweightconcretecontainingunexpanded perlite both as aggregateand as a supplementarycementingmaterial,"Magazine ConcreteResearch, 68, pp. 1-10, 2011.

[28] D. Kramar, V. Bindiganavile, "Mechanicalpropertiesand size effects in lightweightmortarscontainingexpanded perlite aggregate,"MaterialsandStructures, 44, pp. 735-748, 2011.

[29] M. Mamun, V. Bindiganavile, "Mitigatingshrinkagecracking in stuccothroughthereplacement of fineaggregatewithexpanded perlite,"CanadianJournalCivilEngineering, 39, pp. 906-914, 2012.

[30] M. Sriwattanapong, T. Sinsiri, S. Pantawee, P. Chindaprasirt, "A study of lightweightconcreteadmixedwith perlite,"SuranareeJournalof Science\&Technology, 20, pp. 227-234, 2013.

[31] S.G. Abhijeet, V.R.V.Rao, M.V.N. Sivakumar, A. Vasan, M. Venu,A.B. Yaswanth, "Effect of perlite on thermalconductivity of self compactingconcrete,"Procedia-Social and Behavioral Sciences, 104, pp. 188-197, 2013.

[32] D. Kramar, V. Bindiganavile, "Impactresponse of lightweightmortarscontainingexpanded perlite,"CementConcreteComposition, 37, pp. 205-214, 2013. 
[33] S.B. Keskin, K. Sulaiman, M. Sahmaran, İ.Ö. Yaman, "Effect of presoakedexpanded perlite aggregate on thedimensionalstabilityandmechanicalproperties of engineeringcementitiouscomposites," $J$. MaterialCivilEngineering (ASCE), 25, pp. 763-771, 2013.

[34] S.T. Erdoğan, A.U. Sağl1k, "Early-ageactivation of cementpastesandmortarscontainingground perlite as a pozzolan,"CementConcreteComposition, 38, pp. 29-39, 2013.

[35] N. Bozkurt, "Theeffect of hightemperature on concretecontaining perlite powder,"SDU InternationalTechnol. Science, 5, pp. 87-93, 2013.

[36] S. Bakhtiyari, A. Allahverdi, M. Rais-Ghasemi, "A casestudy on modifyingthe fire resistance of selfcompactingconcretewithexpanded perlite aggregateandzeolitepowderadditives, "Asian $J$. CivilEngineering (BHRC), 15, pp. 339-349, 2014.

[37] H.H.M. Darweesh, "Utilization of perlite rock in blendedcement-Part I: physicomechanicalproperties,"Direct Res. J. ChemicalMaterialScience (DRCMS), 2, pp. 1-12, 2014.

[38] A.A. Ramezanianpour, M.M. Karein, P. Vosoughi, A. Pilvar, S. Isapour, F. Moodi, "Effects of calcined perlite powder as a SCM on thestrengthandpermeability of concrete,"ConstructionBuildingMaterial, 66, pp. 222-228, 2014.

[39] H. Oktay, R. Yumrutaş, A. Akpolat, "Mechanicalandthermophysicalproperties of lightweighaggregateconcretes," ConstructionBuildingMaterial, 96, pp. 217-225, 2015.

[40] E.T. Dawood, "Experimentalstudy of lightweightconcreteusedfortheproduction of canoe,"AlRafidainEngineering, 23, pp. 96-106, 2015.

[41] H. Binici, F. Kalayc1, "Production of perlite basedthermalinsulationmaterial,"International Journal of Academic Research and Reflection, 7, pp. 47-54, 2015.

[42] B. Isıkdağ, "Characterization of lightweightferrocementpanelscontainingexpanded perlitebasedmortar,"ConstructionBuildingMaterial, 31, pp. 15-23, 2015.

[43] Y. Maaloufa, S. Mounir, A. Khabbazi, J. Kettar, A. Khaldoun, "Thermalcharacterization of materialsbased on clayandgranular: corkorexpanded perlite,"EnergyProduction, 74, pp. 1150-1161, 2015.

[44] M. Jedidi, O. Benjeddon, C. Soussi, "Effect of expanded perlite aggregatedosage on properties of lightweightconcrete,"Jordon J. CivilEngineering, 9, pp. 278-291, 2015.

[45] J. Zhang, X. Guan, X. Song, H. Hou, Z. Yang, J. Zhu, "Preparationandproperties of gypsumbasedenergystoragematerialswithcapricacid-palmiticacid/expanded perlite composite PCM,"EnergyBuilding, 92, pp. 155-160, 2015.

[46] O. Chung, S.G. Jeong, S. Kim, "Preparation of energyefficientparaffinicCMs/expandedvermiculiteand perlite compositeforenergysaving in buildings,"Sol. EnergyMaterial Sol. Cells, 137, pp. 107-112, 2015.

[47] S. Abidi, B. Nait-Ali, Y. Joliff, C. Favotto, "Impact of perlite, vermiculiteandcement on thethermalconductivity of a plaster compositematerial: experimentalandnumericalapproaches,"Composites Part B: Engineering, 68, pp. 392-400, 2015.

[48] H. Shoukry, M.F. Kotkata, S.A. Abo-El-Enein, M.S. Morsy, S.S. Shebl, "Thermophysicalproperties of nanostructuredlightweight fiber reinforcedcementitiouscomposites,"Construction BuildingMaterial, 102, pp. 167-174, 2016.

[49] S. Abidi, Y. Joliff, C. Favotto, "Impact of perlite, vermiculiteandcement on theYoungmodulus of a plaster compositematerial: experimental, analyticalandnumericalapproaches,"Composites Part B: Engineering, 92, pp. 28-36, 2016.

[50] M. Taherishargh, I.V. Belova, G.E. Murch, T. Fiedler, "On themechanicalproperties of heattreatedexpanded perlite-aluminiumsyntacticfoam,"Materialsand Design, 63, pp. 375-383, 2014.

[51] M. Taherishargh, M.A. Sulong, I.V. Belova, G.E. Murch, T. Fiedler, "On theparticle size effect in expanded perlite aluminiumsyntacticfoam,"Materialsand Design, 66, pp. 294-303, 2015.

[52] P. Krivenko, O. Petropavlovsk11, H. Vozniuk, "Alkalınealumınosilicatebasedadhesivesforconcreteandceramict1les,"RomanianJournal of Materials, 46, pp. 419 - 423, 2016.

[53] Mineral Research and Exploration (MTA), Perlite Nevsehir Detail Study, MTA, Ankara, 1971.

[54] Turkh National Standards, TS EN 13279-1, Gypsum binders and gypsum plasters - Part 1: Definitions and requirements, TürkStandardlarıEnstitüsü, Ankara, 2014. 